DOI 10.26886/2414-634X.6(25)2018.8

UDC: 378.147.091.33-027.22:796]:[373.3:613/614]

\title{
SCIENTIFIC AND APPLIED ASPECTS OF HEALTH-SAVING ACTIVITY REORIENTATION OF PHYSICAL EDUCATION TEACHER PRIMARY SCHOOL
}

\section{G. Panchenko}

Volodymyr Vynnychenko Central Ukrainian State Pedagogical University, Ukraine, Kropyvnytskyi

A new, innovative direction of health-saving - prevention of didactogenic health disorders of primary school pupils, which has arisen as a result of the intensification of school education process, has been considered. The mentioned problem conditions the object of research professional training improvement of would-be teachers of physical education in the specified direction of health-saving. The purpose of the article is formulated as an attempt to substantiate main components and factors of professional readiness of a would-be teacher in the stated direction. The results of the study consist in defining a new notion of "health-saving in the direction of didactogenic health disorders prevention in students," as well as an analysis of the content admission of professional readiness of would-be physical education teacher for the given kind of activity.

Key words: professional readiness of would-be teacher, health-saving technologies, pedagogical activity, intensive training load, health-improving training.

Панченко Г.І. Науково-прикладні аспекти переорієнтації здоров'язбережувальної діяльності учителя фрізичної культури у початковій школі / Центральноукраїнський державний педагогічний університет імені Володимира Винниченка, Україна, Кропивницький

Розглянуто новий, інноваційний напрям здоров'язбереження попередження дидактогенних порушень здоров'я в учнів початкової школи, що виник внаслідок інтенсифрікації процесу шкільного навчання. Зазначена проблема обумовлює предмет дослідження удосконалення професійної підготовки учителя фрізичної культури до досліджуваного напряму здоров'язбереження. Mema cmammi формулюється як спроба обгрунтувати основні складники та чинники профресійної готовності учителя за вказаним напрямом. Результати дослідження полягають у визначенні нового поняття «здоров'язбереження за напрямом попередження дидактогенних порушень здоров'я», а також аналізу змістового наповнення профресійної готовності учителя фрізичної культури до даного виду діяльності. 
Ключові слова: професійна готовність учителя, технології здоров'язбереження, педагогічна діяльність, інтенсивні навчальні навантаження, оздоровчий тренінг.

Постановка проблеми. Початок шкільного життя і новий вид діяльності, пов'язаний 3 нею - навчальною працею, неминуче відбувається на фоні статичних напружень. Вони необхідні для тривалого підтримання певним чином регламентованого положення тіла за партою - навчальною посадкою. Співвідношення між динамічним (більш природнім для дитини) і статичним (штучним, вимушеним) компонентами рухів у порівнянні з дошкільним періодом різко змінюється в бік статичного компонента - першого негативного чинника навчальної праці учнів.

За дослідженням М. В. Антропової, М. М. Кольцової для першокласників статичне напруження тривалістю півгодини призводить до порушення рухливості нервових процесів, зниження розумової i м'язової працездатності, зниження рівня насичення артеріальної крові киснем, подовженому відновлювальному періоду з боку деяких вегетативних фрункцій [5].

Другим основним чинником, що визначає характер негативного впливу навчальної праці, $€$ навантаження на зір. Як зазначає Бальсевич В. К. основний потік навчальної інформації проходить через зоровий аналізатор [2]. 3 початком шкільного навчання у кілька раз зростають обсяг та інтенсивність зорових навантажень у зв'язку з навчанням читанню, письму, рахунку та ін. Принциповим моментом, що надзвичайно підвищує напруженість роботи акомодаційного апарату ока, є зорова робота у переважно ближній зоні, в умовах замкнутого простору класного приміщення при вкрай нестійкій, несформованій навчальній посадці за партою. Це зменшує відстань між оком та зошитом чи книгою до надкритичних значень в плані перенапруження акомодативного апарату зорового аналізатора з 25-30 см за вимогами шкільної гігієни до 8-10 см. Такі умови учнівської праці переключають дитяче око з сигнально-пошукової функції у просторі (що генетично закладено біологічною природою людини) в інструмент напруженої зорової праці в режимі ближнього зору. В цих умовах виникає сенсорний розрив з природнім екологічним середовищем, на яку зорова система має глибоку налаштованість. Тому такі види навчально-пізнавальної діяльності як читання і письмо учні стали виконувати ціною надмірних енергетичних затрат на фоні стомливих статичних та психоемоційних напружень. Зовнішнім проявом такої напруженості дітей $є$, як зазначалось, недопустимо низький нахил тулуба над зошитом і книгою.

Базарний В. Ф. встановив, що при такому положенні навчальної посадки систематичні перевантаження ближнього зору сприяють 
формуванню напруження, яке через систему нервових зв'язків трансформується у синдром психоемоційного та нейровегетативного напруження i, як наслідок, хронічну втому дітей в ході навчального процесу. Тривале перебування дітей у напруженому, 3 низько схиленою головою, стані формує так званий рефлекс низько схиленої голови (РНСГ), що пригнічує найважливіші вегетативні ритми організму [1]. У свою чергу це призводить до астенізації дітей, пригніченню розвитку центральної і вегетативної нервових систем, що зрештою накладає глибокий несприятливий відбиток на їх фрізичний, функціональний і психічний розвиток.

Підсумком відмічених складових, що характеризують постійно зростаючої інтенсифрікації навчальної праці учня, $€$ виникнення короткозорості, порушення постави, серцево-судинні та нервовопсихічні дисфункції.

Аналіз останніх публікацій. Проблема здоров'язбереження учнів складна та багатогранна, її розв'язання потребує комплексних міждисциплінарних підходів і зусиль представників різних наук.

Дидактичні аспекти здоров'язбереження розглянуті в дослідженнях О. М. Ващенка, О. Д. Дубогай, Г. К. Зайцева, Т. В. Кудрявцева, О. Я. Савченко, та ін.

Медико-біологічні сторони здоров'язбереження учнів висвітлені у роботах М. М. Амосова, М. В. Антропової, В. Ф. Базарного, Е. Г. Буліч, С. М. Громбаха, Ю. Л. Лісіцина, І. В. Муравова, В. М. Петленко, Л. П. Сущенко та ін.

Психологічні аспекти проблеми досліджувалися в працях І. Д. Беха, В. Л. Лєві, Г. С. Нікіфорова, С. Д. Максименка, О. В. Хухлайової.

Поняття «здоров'язбереження» у сучасній педагогічній науці почало активно використовуватися 3 другої половини 80-х років минулого століття, що пов'язано з наростанням динаміки різкого погіршення здоров'я учнів (М. Антропова, Г. Апанасенко, М. Гончаренко, Н. Лосєва, С. Максименко, А. Найн, С. Сімонова, С. Сєріков, А. Хріпкова). Але різність поглядів, складність проблеми продукувало наступні різні визначення терміна «здоров'язбереження».

Так, Сєріков С. Г здоров'язбереження учнів розглядає як єдність педагогічних заходів, спрямованих на покращення здоров'я учнів і зростання їх освіченості [7]. У педагогічному контексті Єфрімова В.М. також пропонує розглядати здоров'язбереження як систему педагогічних дій, які дозволяють не витрачати марно, не руйнувати фрізичне, психічне і соціальне благополуччя дітей і підлітків, що реалізується через освітні технології 3 урахуваннями вікових і психофрізичних особливостей учнів [3].

Прибічник комплексного підходу Красілов В. М. для розв'язання проблеми розглядає фрактори впливу ширше. Здоров'язбереження у навчальному закладі трактується як спрямовано здійснюваний у 
виховному освітньому процесі комплекс науково обґрунтованих педагогічних психологічних, лікувальних, профрілактичних, корекційних та інших впливів на суб'єкти освітньої діяльності, які нерозривно пов'язані з розв'язанням завдань навчання, виховання, розвитку, збереження їх здоров'я [4].

Мета даної статті полягає у виокремленні нового напряму сучасного здоров'язбереження учнів початкової школи - попередження дидактогенних порушень здоров'я та визначенні і обґрунтуванні основних складників профресійної підготовки учителя фрізичної культури до здоров'язбережувальної діяльності зазначеного напряму.

Виклад основного матеріалу. Аналіз наведених тлумачень терміна «здоров'язбереження» свідчить, що при всіх відмінностях авторів об'єднує розуміння того, що це $є$ по суті різновид «педагогічної діяльності». Таким чином поняття «здоров'язбережувальна педагогічна діяльність» $\epsilon$ тією консолідуючою основою, що спрямовує всі зусилля шкільного колективу на формування та зміцнення здоров'я всіх учасників навчального процесу (Д. Є. Воронін, В. М. Єфрімова, К. В. Короленко, П. В. Красавцев, Т. Ю. Круцевич, Н. М. Мацкевич, О. І. Міхеєнко, В. П. Мазура, Ю. В. Науменко, А. С. Нісімчук, С. О. Омельченко, В. Г. Омельяненко, В. М. Оржеховська, О. С. Падалка, М. К. Смірнов, О. Т. Шпак).

За характеристикою Смірнова М. К. основна фрункція здоров'язбережувальної педагогічної діяльності полягає у тому, щоб забезпечити можливість кожному учню зберегти свій рівень здоров'я за час шкільного навчання, сформувати у нього систему знань, умінь, навичок та переконань щодо ведення здорового способу життя. По суті це $\epsilon$ стратегічна мета здоров'язбережувальної педагогіки, що представлена такими якісними характеристиками педагогічного процесу, які через сукупність валеологічних, за своєю сутністю, принципів, прийомів, методів педагогічної діяльності реалізовують завдання збереження здоров'я [8].

Таким чином, під здоров'язбереженням в межах нашого дослідження ми розуміємо спеціально організовану педагогічну діяльність учителя фрізичної культури, що має на меті попередження дидактогенних порушень та захворювань, яка спрямована на реалізацію таких заходів, методів і фрорм фрізичного виховання, що удосконалюють процес навчання у початковій школі, забезпечуючи повноцінний оздоровчо-тренувальний супровід навчальної праці.

Отже, метою здоров'язбережувальної педагогічної діяльності $€$ захист здоров'я школярів від впливу негативних компонентів інтенсивних навчальних навантажень. Одним із головних фракторів успішної реалізації поставленої мети $є$ здоров'язбережувальна педагогічна діяльність учителя фрізичної культури, який не тільки має навчати руховим діям і розвивати фрізичні здібності учнів, але й 
запроваджувати у навчальний процес початкової школи сучасні технології попередження дидактогенних порушень і захворювань засобами, методами і фрормами оздоровчого тренінгу.

Здоров'язбережувальна діяльність учителя фрізичної культури за напрямом попередження дидактогенних порушень здоров'я - це система оздоровчо-тренувального супроводу навчальної праці учня початкової школи з метою повноцінної адаптації організму дитини до специфріки навчальної праці.

У дисертаційному дослідженні О. В. Омельченко [6] розроблена модель підготовки учителя до запровадження здоров'язбереження учнів початкових класів. В основу моделі покладено фрормування мотиваційно-ціннісного і когнітивного компонентів професійнопедагогічної діяльності учителя з організації здоров'язбережувального навчально-виховного процесу. Мотиваційно-ціннісний компонент передбачає свідоме бажання учителя здійснювати духовне наставництво дитини на шляху її здорового розвитку. Це реалізується через сорормованість сукупності таких особистісно-значущих якостей як відповідальність, працездатність, педагогічний такт, симпатія та ін., що теж відіграє значну роль та обумовлює ефективність роботи учителя. Якість когнітивно-процесуального компонента даної моделі пропонується оцінювати за рівнем гностичних, прогностичних, комунікативних, організаторських знань та умінь, які необхідні для організації, збереження і зміцнення здоров'я дітей.

\section{Висновки.}

1. Сучасний процес стрімкої інтенсифрікації шкільного навчання породжує протиріччя, сутність якого полягає у виникненні дидактогенних порушень здоров'я, нозологія яких безпосередньо пов'язана з негативним впливом статичного, зорового та нервовоемоційного компонентів навчального навантаження. Це новий виклик сучасній шкільній освіті, який вимагає спеціальної здоров'язбережувальної підготовленості учителя фрізичної культури.

2. Показниками профресійної готовності учителя фрізичної культури до роботи зазначеного напряму є наступне:

- рівень поінформованості щодо вибору здоров'язбережувальних технологій з урахуванням закономірностей та вікових індивідуальних особливостей адаптації організму дітей до навчальних навантажень;

- рівень відповідальності до проведення роботи з попередження дидактогенних порушень здоров'я;

- здатність до реалізації відібраних технологій здоров'язбереження.

Перспективи подальших розвідок полягають у розробці оновленого змісту і спрямованості підготовки майбутнього учителя фрізичної культури до здоров'язбережувальної роботи з учнями початкової школи. 


\section{Лumepamypa:}

1. Базарный В. Зрение у детей: проблемы развития / В. Базарный Новосибирск: Наука, Сиб. отделение, 1991. - 140 с.

2. Бальсевич В. К. Концепция альтернативных форм организации фризического воспитания детей и молодежи [Текст] / В. К. Бальсевич // Физическая культура: воспитание, образование, тренировка. 1996. - № 1. - C. 23-25.

3. Єфрімова В. М. Здоров'язбережувальний компонент професійної підготовки майбутніх фрахівців / В. М. Єфрімова, О. А. Георгіаді // Педагогіка, психологія та медико-біологічні проблеми фрізичного виховання і спорту. . - 2009. - № 12. - С. 61-65.

4. Красилов В. М. Здоровьсберегающий поход $к$ организации воспитательно-образовательного процесса в учреждених начального профрес. образования: автореф. дис. канд. пед. наук. 13.00.08 / В. М. Красилов. - Новокузнецк, 2009. - 24 с.

5. Морфрофункциональное созревание основных фризиологических систем организма детей дошкольного возраста / [под ред. М. В. Антроповой, М. М. Кольцовой]. - М.: Педагогика, 1983. - 160 с.

6. Омельченко О. В. Особливості просресійно-педагогічної діяльності вчителя початкових класів 3 організації здоров'язберігаючого навчально-виховного процесу: авторефр. дис. ...канд. пед. наук: 13.00.04 / О. В. Омельченко. - Х., 2008- 20 с.

7. Сериков С. Г. Обеспечение паритета образованности и здоровья учащихся в теории и практике образования: дис. ...доктора пед. наук: 13.00.01 / С. Г. Сериков - Челябинск, 2002. - 385 с.

8. Смирнов H. К. Здоровьесберегающие образовательные технологии и психология здоровья в школе / Н. К.Смирнов. - М.: АРТИ, 2005. - 299 c.

\section{References:}

1. Bazarnyy V. Zrenie u detey: problemy razvitiya [Eyesight of children: development problems]/V. Bazarnyy - Novosibirsk: Nauka, Spb. otdelenie, 1991. - $140 \mathrm{~s}$.

2. Balsevich V. K. Kontseptsiya alternativnykh form organizatsii fizicheskogo vospitaniya detey i molodezhi [Tekst] [Concept of alternative forms of organization of physical education of children and youth] / V. K. Balsevich // Fizicheskaya kultura: vospitanie, obrazovanie, trenirovka. 1996. - \# 1. - S. 23-25.

3. Yefimova V. M. Zdorov'iazberezhuvalnyi komponent profesiinoi pidhotovky maibutnikh fakhivtsiv [Health-saving component of professional training of would-be specialists] / V. M. Yefimova, O. A. Heorhiadi // Pedahohika, psykholohiia ta medyko-biolohichni problemy fizychnoho vykhovannia i sportu. . - 2009. - № 12. - S. 61-65. 
4. Krasilov V. M. Zdorovsberegayushchiy pokhod $k$ organizatsii vospitatelno-obrazovatelnogo protsessa $v$ uchrezhdenikh nachalnogo profes. obrazovaniya [Health-saving approach for the organization of upbringing and educational process in primary prof. educational establishments]: avtoref. dis. kand. ped. nauk. 13.00.08 / V. M. Krasilov. Novokuznetsk, 2009. - 24 s.

5. Morfofunktsionalnoe sozrevanie osnovnykh fiziologicheskikh sistem organizma detey doshkolnogo vozrasta [Morphofunctional maturation of basic physiological systems of preschool children's organism] / [pod red. $M$. V. Antropovoy, M. M. Koltsovoy]. - M.: Pedagogika, 1983. - $160 \mathrm{~s}$.

6. Omelchenko O. V. Osoblyvosti profesiino-pedahohichnoi diialnosti vchytelia pochatkovykh klasiv z orhanizatsii zdoroviazberihaiuchoho navchalno-vykhovnoho protsesu [Features of professional and pedagogical activity of primary school teacher in organization of health-saving upbringing and educational process]: avtoref. dys. ...kand. ped. nauk: 13.00.04 / O. V. Omelchenko. - Kh., $2008-20$ s.

7. Serikov S. G. Obespechenie pariteta obrazovannosti i zdorovya uchashchikhsya $v$ teorii $i$ praktike obrazovaniya [Providing parity of students' education and health in the theory and practice of education]: dis. ...doktora ped. nauk: 13.00.01 / S. G. Serikov - Chelyabinsk, 2002. - 385 $s$.

8. Smirnov N. K. Zdorovesberegayushchie obrazovatelnye tekhnologii i psikhologiya zdorovya $v$ shkole [Health-saving educational technologies and psychology of health at school] / N. K.Smirnov. - M.: ARTI, 2005. - 299 $s$. 